\title{
RECONSTRUCTION OF EDUCATIONAL SCIENCE WITH PROPHETIC PARADIGM IN FACULTY OF TARBIYAH AT IAI MUHAMMADIYAH BIMA
}

\author{
Ruslan \\ Institute of Islamic Studies (IAI) Muhammadiyah Bima \\ Email: ruslanamarizqi@gmail.com \\ Luthfiyah \\ Institute of Islamic Studies (IAI) Muhammadiyah Bima \\ Email: luthfiyah.inarizqi@gmail.com
}

\begin{abstract}
The Tarbiyah Faculty of IAI Muhammadiyah Bima still uses educational science reference books, which nota bene does not contain prophetic elements explicitly. Reference books are students' reference source to discover their knowledge, enrich the treasure of scholarly, and construct their thinking paradigm. This research aims to develop Educational Science reference by integrating prophetic values. This library research used philosophical and sociological approaches. The data source were educational science books, prophetic books, and others. The results showed that the reconstruction of educational science reference books by prophetic values construct civilized man, educated and well behaved as a humanist. It also optimized students' critical and creative capacity, delivering the thinking system from the shackles of culture and tradition, class and sex dominations, and eliminating the oppression. Transcendentally construct their inners as God creatures who have to be responsible for themselves, their society, and nature. It has to balance between observable and unobservable matter by developing a method to stop stagnation of scholarly. The goal is to create prophetic students.
\end{abstract}

Abstrak: Fakultas Tarbiyah IAI Muhammadiyah Bima masih menggunakan buku referensi ilmu pendidikan yang notabene tidak mengandung unsur profetik secara eksplisit. Buku referensi merupakan sumber rujukan siswa untuk menemukan ilmunya, memperkaya khazanah keilmuan, dan membangun paradigma berpikirnya. Penelitian ini bertujuan untuk mengembangkan referensi Ilmu Pendidikan dengan mengintegrasikan nilai-nilai profetik. Penelitian pustaka ini menggunakan pendekatan filosofis dan sosiologis. Sumber datanya adalah buku ilmu pendidikan, buku-buku profetik, dan lain-lain. Hasil penelitian menunjukkan bahwa rekonstruksi buku referensi ilmu pendidikan dengan nilai-nilai profetik mampu membentuk manusia yang beradab, berpendidikan dan berperilaku baik sebagai manusia. Selain itu, hal tersebut 
juga mengoptimalkan kapasitas kritis dan kreatif siswa, melahirkan sistem berpikir dari belenggu budaya dan tradisi, dominasi kelas dan jenis kelamin, serta menghilangkan penindasan. Secara transendental, membangun batin mereka sebagai makhluk Tuhan yang harus bertanggung jawab atas diri sendiri, masyarakat, dan alamnya. Hal ini harus mampu menyeimbangkan antara materi yang dapat diamati dan yang tidak dapat diamati dengan mengembangkan metode untuk menghentikan stagnasi ilmiah. Tujuannya adalah untuk menciptakan siswa yang profetik.

Keywords: reference book; educational science; prophetic

\section{INTRODUCTION}

Reference books are one of the prerequisites that must be available in the lecturing process since teaching materials are in the form of knowledge, skills, attitudes or values that must be learned to achieve predetermined competency standards. ${ }^{1}$ Reference books become references, opinions proponents and the style of thought determiner where the students' thinking paradigm will be directed. Therefore, reference books must be prepared in accordance with scientific concentration and an accountable study focus.

Reference books have a n "epistemic" and "authority" function in the academic actualization process. The epistemic function is indicated by the role of reference books in influencing perspectives, insights, what is thought and what is not thought of by both lecturers and students. Yet, the function of authority can be seen from the final information provided by reference books. It is because, for some people, reference books are seen as a representation of reality, like a holy book that contains absolute truth, does not accept review and change (ghair qabil al-niqasy wa al-taghyir). ${ }^{2}$ This fact will be one of the sources of scientific stagnation.

Whereas, reference books should consider several criteria, namely: validity, significance, utility and consistency with social reality. ${ }^{3}$ Once the reference book does not meet these criteria, then it is time to be replaced or reconstructed. It is because in selecting learning materials, there are principles that should be followed. They are principles of relevance, consistency and sufficiency principles. ${ }^{4}$

1 Karliana Indrawari and Sayyid Habiburrohman, 'Pengembangan Bahan Ajar Pendidikan Agama Islam Dengan Metode Al-Qur `An Tematik', Cendekia Vol. 17 No 1 (June 2019): 17-35.

2 Mahmud Arif, 'Tipologi Buku Referensi Kependidikan Islam di Fakultas Tarbiyah UIN Sunan Kalijaga Studi Pustaka atas Akar Involusi Konsep Kependidikan Islam', Penelitian (Yogyakarta: UIN Sunan Kalijaga, 2007), 4.

3 Abdullah Idi, Pengembangan Kurikulum Teori dan Praktik (Yogyakarta: Ar-Ruzz Media, 2010), 195-99.

4 Indrawari and Habiburrohman, 'Pengembangan Bahan Ajar Pendidikan Agama Islam Dengan Metode Al-Qur`An Tematik'. 
Any material given to students through reference books used in teaching and learning process must consider several of these criteria, including the educational science reference books used at the Tarbiyah Faculty of IAI Muhammadiyah Bima. So far, several reference books that are used as sources for educational science courses do not explicitly contain prophetic values. In this context, it is necessary to internalize the value of humanization, liberation and transcendence 5 into the science of education.

The existing references do not show the nature of education. Besides, there are significant differences between education and Educational Science (pedagogy). When education is a process of transforming knowledge as well as values to make people know better, become smarter and more mature, or more focused on the process of implementing education, then the science of education is more about how to achieve all of this. It means that education is oriented towards practical matters, while pedagogy is more theoretical. Even some experts interpret education as art in educating. ${ }^{6}$

Talking about the art of educating, we cannot separate it from the values on which it is based. In this study, the values of prophetic social science become values integrated into the pedagogy. ${ }^{7}$ They are considering that recently, the reality shows that there have been frequent cases of violence, fighting and even murder in Bima, where the perpetrators whose jobs are teachers and students. In other words, there has been dehumanization, deliberation and detranscendence in the educational field, in which the best solution is urgently needed.

Therefore, according to Amin Abdullah, the need to develop both prophetic social science and contextual religious studies in Public Universities is a serious concern about the direction of development and learning objectives of general sciences that have been practised. ${ }^{8}$ Islamic tertiary institutions must also carry out innovation and transformation in terms of teaching materials and methodology since there are undeniable facts that the education system in Indonesia still needs to be improved. Therefore the academics should be able to develop research

5 Kuntowijoyo, Identitas Politik Umat Islam (Bandung: Mizan, 1997).

6 Arif Rohman, Memahami Pendidikan dan Ilmu Pendidikan (Yogyakarta: Mediatama, 2009), 11; Abu Ahmadi, Ilmu Pendidikan (Jakarta: Rineka Cipta, 2003), 90-93.

7 The pos sibility of scientific development by integrating the three values of social prophetic science is the answer to the fact that science has a dynamic and revolutionary character. According to Arifin, this integration is considered important because there has been a vacuum in the field of science based on Islam. Syamsul Arifin, 'Dimensi Profetisme Pengembangan Ilmu Sosial dalam Islam Perspektif Kuntowijoyo', Teosofi: Jurnal Tasawuf dan Pemikiran Islam 4, no. 2 (Desember 2014).

8 Muhammad Amin Abdullah, 'Etika Tauhidik sebagai Dasar Kesatuan Epistemologi Keilmuan Umum dan Agama', in Strategi Pendidikan: Upaya Memahami Wahyu Dan Ilmu (Yogyakarta: Pustaka Pelajar, 2010). 
that maps the vulnerable aspects of Indonesia's education system and provides solutions to cover those shortcomings. ${ }^{9}$

This cond ition is not only for public universities but also for religious universities. According to the author, it is a religious university (Islam) that should be more concerned with planting Islamic values, including prophetic values. In addition to transforming knowledge, religious colleges are also required to instil religious values (Islam). Besides, education, especially those managed by Muslims, needs content that encourages Islam to appear as a religion that displays grace in the among the world community, so that Islam appears to be a friendly, tolerant and moderate religion without losing its dignity. ${ }^{10}$

The condition of education in Indonesia has encountered various unpleasant stigmas, given that the problems encountered by the education system in Indonesia have not been solved Tilaar stated pessimistically that «the science of education in Indonesia is living in a border situation». ${ }^{11}$ Even more, ironically, Mochtar Buchori stated that "educational science in Indonesia is experiencing an identity crisis, which sounds a death knell". ${ }^{12}$

Therefor e to overcome this, the development of Educational Science based on prophetic values is needed. Although almost all of the development of teaching materials have followed the applicable curriculum, there are still minimal sources of material from the Quran. Based on this phenomenon, Indrawari to ok a step trying to develop a Quran based material. It becomes an enrichment of PAI (Islamic studies) material at PTU (non-Islamic-major university) as well as reference material for PTU in conducting PAI courses. ${ }^{13}$ Abdul Munip has also developed Islamic Studies, by first understanding the map of the study area, which should be projective-identifiable. According to him, the stagnation in the study area of Islamic studies requires theories that enrich philosophical studies and empirical validation. ${ }^{14}$ In Mahmud Arif's research, it was concluded that in general, the treasures of Islamic studies literature had not

9 Muhammad Amin Abdullah, 'Islamic Studies in Higher Education in Indonesia: Challenges, Impact and Prospects for the World Community', Al-Jami'ah: Journal of Islamic Studies 55, no. 2 (15 December 2017): 391-426.

${ }^{10}$ Hadi Purnomo and Umiarso, 'Pengelolaan Dan Sistem Pendidikan Islam Berwawasan Rahmatan Lil 'Alamin: Kajian Atas Gerakan Pendidikan Fethullah Gulen Movement', Cendekia: Jurnal Kependidikan Dan Kemasyarakatan Vol 16, No 2 (2018): 228.

${ }^{11}$ HAR Tilaar, Perubahan Sosial dan Pendidikan: Pengantar Pedagogik Transformatif untuk Indonesia (Jakarta: Rineka Cipta, 2014).

${ }^{12}$ Mochtar Buchori, Ilmu Pendidikan dan Praktek Pendidikan dalam Renungan (Yogyakarta: Tiara Wacana, 1994), 1-9.

${ }^{13}$ Indrawari and Habiburrohman, 'Pengembangan Bahan Ajar Pendidikan Agama Islam Dengan Metode Al-Qur 'An Tematik', 18.

${ }^{14}$ Abdul Munip, 'Pengembangan Ilmu Pendidikan Islam: Pemetaan Wilayah Kajian', JIPI 6, no. 1 (2005): 44-45. 
moved from normative-reproductive reasoning. It should be able to appreciate critical paradigm, contextualization and empirical research. As a result, reference books are less contributive to the process of formulating and developing Islamic education. ${ }^{15}$

In addition to development in the field of education, another development is also carried out to apply prophetic values in various scientific disciplines. Syarifuddin Jurdi, for example, has introduced a new paradigm of social reality from a prophetic perspective. ${ }^{16}$ Prophetic sociology referred to as social science with a prophetic paradigm, which is based on the values of humanization, liberation and transcendence. According to him, p rophetic sociology is methodologically dealing with positivism, so the source of knowledge is based on social reality, ratio and also a revelation.

Moh. Shofan has also attempted to realize a prophetic paradigm by eliminating the dichotomy between the traditional and modern Islamic education models because in social life, Islamic education interacts with other social institutions and the response of Islamic education is partly assimilative and alienative. $\mathrm{He}$ offers the concept of Islamic education with a prophetic paradigm that is not only seen as a value but also as a theory, including humanization, liberation and transcendence. ${ }^{17}$

Although many have studied prophetic values, this research specifically seeks to construct a new paradigm in the area of educational science reference books with a prophetic paradigm, namely those based on the values of humanization, liberation and transcendence which will be the three pillars of the realization of prophetic education. Besides, this research focuses its study area on the Tarbiyah Faculty of IAI Muhammadiyah Bima, which so far uses education al science reference books which do not explicitly contain prophetic values.

This research is significant in educational studies viewed from several things, namely: a) finding new theories or concepts about Educational Science reference books based on prophetic values in Bima; b) testing the application of the theory or Kuntowijoyo's concept of prophetic social science, which contains the values of humanization, liberation and transcendence into the practice area in the field (IAI Muhammadiyah Bima); c) emerging to innovations to enrich the theories or concepts contained in the Educational Science reference books as a result of an in-depth study of existing theories or concepts.

${ }^{15}$ Arif, 'Tipologi Buku Referensi Kependidikan Islam di Fakultas Tarbiyah UIN Sunan Kalijaga Studi Pustaka atas Akar Involusi Konsep Kependidikan Islam’.

${ }^{16}$ Syarifuddin Jurdi, 'Sosiologi Profetik: Invitasi Islam Bagi Studi Sosial Dan Kemanusiaan' (Yogyakarta: Saroba, 2009).

${ }^{17}$ Moh. Shofan, Pendidikan Berparadigma Profetik: Upaya Konstruktif Membongkar Dikotomi Sistem Pendidikan Islam (Yogyakarta: Ircisod, 2004). 


\section{RESEARCH METHOD}

This research employed as library research using a philosophical approach ${ }^{18}$ and sociological approach. ${ }^{19}$ Data were obtained through literature study and literature review of the Educational Science reference books, Kuntowijoyo's book on prophetic values and other related works. Data were analyzed by using content analysis techniques ${ }^{20}$ for literature, such as books, articles and journals through data procurement procedures, data reduction (reduction), data analysis and inference. ${ }^{21}$

\section{REFERENCES AND PARADIGM OF PROPHETIC SOCIAL SCIENCE The Urgency of Reference Books during the Paradigm Revolution}

Reference books can be seen from two perspectives, as cultural products and as the mean of producing culture. ${ }^{22}$ Reference books as cultural products are the result of a flow of thought that has developed as a reflection of the «social knowledge" disposition. It can be seen in the teaching and learning model that is oriented towards preserving science, so books containing alternative thinking ideas are usually less desirable.

Meanwhile, from the second perspective, reference books have a major role in generating discourse, stimulating intellectual activity, as well as formatting the scientific domain. One phenomenon that becomes an example that could strengthen the unction of books as a means to produce a certain culture happens when a book review is held every time a new book is launched. It is considered to enrich discourse within the campus environment. Based on the phenomenon, as mentioned earlier, Komaruddin Hidayat's opinion seems quite reasonable. He stated that books play an enormous role in influencing the mindset and behavior of readers. ${ }^{23}$

It is in line with Thomas Khun's theory of revolutionary paradigm that within scientific discourse, there is always a possibility to produce to new paradigms. A paradigm in a scientific field will be followed by a revolution paradigm in the next period, because of its inability to answer new problems.

${ }^{18}$ Anton Bakker, Metodologi Penelitian Filsafat (Yogyakarta: Kanisius, 1990), 35.

${ }^{19}$ Michael S Northcott, 'Pendekatan Sosiologis', in Aneka Pendekatan Studi Agama (Yogyakarta: LKiS, 2002), 267; Ronald Robertson, Agama dalam Analisa dan Interpretasi Sosiologis (Jakarta: Raja Grafindo, 1992), 72.

${ }^{20}$ Lexy J Moleong, Metodologi Penelitian Kualitatif (Bandung: Remaja Rosdakrya, 2007), 279.

${ }^{21}$ Darmiyati Zuchdi, Panduan Penelitian Analisis Konten (Yogyakarta: Lemlit UNY, 1993), 28-36.

${ }^{22}$ Arif, 'Tipologi Buku Referensi Kependidikan Islam di Fakultas Tarbiyah UIN Sunan Kalijaga Studi Pustaka atas Akar Involusi Konsep Kependidikan Islam', 2-3.

${ }^{23}$ Komaruddin Hidayat, 'Pengantar', in Sembilan Jalan Cerdas Emosi dan Cerdas Spiritual (Jakarta: Hikmah, 2006), xxi. 
Revolution can also be carried out in other fields of study and scholarship. In fact, according to Khun, science moves through stages which will culminate in normal conditions and gradually «rot» because it is replaced by new knowledge or paradigms. ${ }^{24}$ This cycle will continue to rotate because of the emergence of anomalies and demands and needs of society. The emergence of a new paradigm will initially be considered threatening the old paradigm, which previously had also become a new paradigm. The result is in the process of clashes and wars between paradigms. ${ }^{25}$ Khun emphasized that the crisis is precisely a necessary and important precondition for the emergence of new theories, and in the end, a new paradigm that is more able to answer this need will be recognized. ${ }^{26}$

Johnson described Khun's paradigm shifted through four phases: the preparadigmatic stage, the paradigmatic stage, the transitional revolutionary stage (as long as one paradigm is challenged by several emerging and increasing anomalies) and the emergence of a counter paradigm which then happened to create a new paradigm that shifts the old paradigm. Thus, it means that the paradigm will always be renewed as a continuous cycle. ${ }^{27}$

According to Friedrichs, Khun's "paradigm» is the best example that can act as a frame of reference, because it is a definition of a particular situation that can become the fundamental focus of orientation. Without a paradigmatic foundation, all problems, methods and objectives of all the facts and criteria for identifying solutions will appear equally relevant. So the "paradigm» is correlated with a compass by which everything can be mapped. ${ }^{28}$

This research is a transitional revolution by constructing a counter paradigm. Prophetic Educational Science is a counter paradigm intended to replace the old paradigm to be able to answer the current anomalies as an effort to restore the main function of Educational Science (pedagogy). As an offer, the concept of developing prophetic education will not only be a new theory but also as a value. Given that the function of education is not only the transfer of knowledge but also the transfer of value and the transfer of methodology at the same time, so that intellectual, emotional and spiritual intelligence is obtained in a balanced

${ }^{24}$ Ziauddin Sardar, Thomas Khun dan Perang Ilmu (Yogyakarta: Jendela, 2002).

${ }^{25}$ Thomas S Khun, The Structure of Scientific Revolutions -Peran Paradigma dalam Revolusi Sains (Bandung: Remaja Rosdakrya, 2000).

${ }^{26}$ Khun, 77.

${ }^{27}$ This the paradigm cycle, where a scientist works in a paradigm framework for a long time. However, in its development there are anomalies that continue to develop and accumulate gradually and it eventually becomes difficult to explain them with the existing paradigm. Thus, a paradigm development is needed as a counter to the old paradigm. Doyle Paulo Johnson, Teori Sosiologi Klasik dan Modern (Jakarta: Gramedia Pustaka Utama, 1994), 54.

${ }^{28}$ Robert W Friedrichs, A Sociology of Sociology (London: Free Pers, 1972), 4. 
manner. It, of course, can be done by making three prophetic values as the pillars of its development.

\section{Prophetic Social Sciences}

Prophetic social science is the result of Kuntowijoyo's derivation of QS. Ali Imran: 110. According to him, the verse contains four things that are implied, namely: first, the concept of Muslims being the best community (khaira ummah); second, historical activism; third, the importance of awareness of divine values (ma'ruf, munkar, iman/faith) as the foundation of Islamic activism; fourth, prophetic ethics. $^{29}$

Prophetic social science as a formulation of Islamic social theory aims to make Muslims able to actualize faith in objective reality, as well as able to manifest charity effectively in new social conditions and realities. ${ }^{30}$ It is because Islam will be of great benefit to human life if it can be constructed into scientific theories. ${ }^{31}$ It even needs to be developed, both in social and religious studies. ${ }^{32}$ People need to understand Islam as a science and within the framework of science. By using a scientific framework, especially an empirical one, Muslims can understand a reality so that they can carry out transformation or change. ${ }^{33}$ In Zuly Qodir's term, we should leave the myth behind and make progress through science, so that reality does not become a pseudo-reality, but lives within the society. ${ }^{34}$ Strictly speaking, Kuntowijoyo wants to integrate Islam into a new historical consciousness that is universal and more humanist. ${ }^{35}$

In constructing prophetic social science, Kuntowijoyo did not avoid conventional Western theories. Besides, he also undertakes the "enrichment" in theories synthesis, which according to M. Dawam Rahardjo it is called a «twisting» on the theories he borrowed. ${ }^{36}$ As support for this statement, Roger Garaudy's statement is very relevant. He stated that amid the destruction of

${ }^{29}$ Kuntowijoyo, Muslim Tanpa Masjid (Bandung: Mizan, 2001), 357-58.

${ }^{30}$ Kuntowijoyo, Paradigma Islam: Interpretasi Untuk Aksi (Yogyakarta: Tiara Wacana, 2013); 345.

${ }^{31}$ Kuntowijoyo, Dinamika Sejarah Umat Islam (Yogyakarta: SP dan Pustaka Pelajar, 1994), 39.

${ }^{32}$ M. Amin Abdullah, 'Etika Tauhidik Sebagai Dasar Kesatuan Epistemologi Keilmuan Umum dan Agama (Dari Paradigma Positivistik-Sekularistik ke Arah TeoantroposentrikIntegralistik', in Integrasi Sains-Islam: Mempertemukan Epistemologi Islam dan Sains (Yogyakarta: Pilar Media, 2004), 7-8.

${ }^{33}$ M. Syafi'i Anwar, Pemikiran dan Aksi Islam Indonesia: Sebuah Kajian Politik tentang Cendekiawan Muslim Orde Baru (Jakarta: Paramadina, 1995), 172.

${ }^{34}$ Zuly Qodir, 'Kuntowijoyo Dan Kebudayaan Profetik', PROFETIKA, Jurnal Studi Islam Vol. 16, No. 1 (June 2015): 103-13.

${ }^{35}$ Moeslim Abdurrahman, Islam Transformatif(Bandung: Pustaka Firdaus, 1999), 102.

${ }^{36}$ M. Dawam Rahardjo, 'Ilmu Sejarah Profetik Dan Analisis Transformasi Masyarakat', in Paradigma Islam (Bandung: Mizan, n.d.), 17. 
human civilization where Western philosophy has many weaknesses, Muslims should be able to revive the existing Islamic heritage, which is taken from the philosophy of Islamic prophecy itself. ${ }^{37}$ According to Muttaqin, Kuntowijoyo's idea is similar to critical theory, but it has a plus point through its transcendent value, which will answer the relationship between religions and social science. ${ }^{38}$

The three prophetic ideals are directed towards society implementation for its socio-ethical ideals in the future ${ }^{39}$ because the problem of the people now is how to deliver the ummah in the transformation towards an industrial society, civil society, non-exploitative economy, democratic society, a rational state and humane culture. ${ }^{40}$ Prophetic implementation includes the development of educational science. Because after all education is the main and the last pillar -after improvements in the fields of economy, social, culture and political resilience - which is anticipated for being able to restore a nation's downturn. It is because progress will be difficult to achieve if it is not supported by progress in education. ${ }^{41}$

It means that education is the most important factor in fostering humankind. Education is still considered as the main helper for humans to live this life. Therefore there is an emerging extreme thesis stated that the education determines a nation's civilization progress and retreat that the nation undergoes. Accordingly, education must be used as one of the central themes of the plan for reconstructing the future vision. In the end, this ijtihad certainly hopes for the realization of abundant change and improvement in society, starting from the campus as a miniature of society. A humanist, liberatory and transcendental society is the manifestation of a prophetic society.

\section{RECONSTRUCTION OF EDUCATION THROUGH THREE PILLARS OF PROPHETIC SOCIAL SCIENCE}

Prophetic Values and Their Urgency for Reconstructing Educational Sciences Prophetic social science, according to Kuntowijoyo, is a transformative social science which is based on the results of «the elaborating the teachings of religions into the form of a social theory». Its main target is «implementation for social transformation». Its scope is not only on aspects that are normative-permanent like theology but more on aspects that are empirical, historical and temporal. ${ }^{42}$

${ }^{37}$ Roger Garaudy, Janji-Janji Islam (Jakarta: Bulan Bintang, 1984).

${ }^{38}$ Husnul Muttaqin, 'Menuju Sosiologi Profetik', Sosiologi Reflektif Volume 10, N0. 1 (Oktober 2015): 224.

${ }^{39}$ Kuntowijoyo, Islam Sebagai Ilmu: Epistemologi, Metodologi, dan Etika (Bandung: Mizan, 2005), 92.

${ }^{40}$ Rahardjo, 'Ilmu Sejarah Profetik Dan Analisis Transformasi Masyarakat', 108.

${ }^{41}$ Mahmud Arif, Pendidikan Islam Transformatif (Yogyakarta: LKiS, 2008), 293.

${ }^{42}$ Kuntowijoyo, Islam Sebagai Ilmu: Epistemologi, Metodologi, dan Etika, 85. 
The transformation that becomes the ideals and goals of this prophetic social science has transformational implications. Suppose the implications are used by scientists in their research, according to Ahimsa Putra. In that case, it means that cultural transformation has occurred, because the prophetic paradigm contains basic assumptions (life outlook), values. (ethos), and a view of the world (model) that is different from other paradigms. Likewise, the results of work or research reports that use a prophetic paradigm will certainly produce something (as a result of cultural transformation) which is different from using a non-profit paradigm. ${ }^{43}$

So this research will result in a prophetic cultural transformation that is not only in the realm of ideas and knowledge but more in the realm of scientific applicative so that it will have benefits for the creation of social transformation that is initiated by individual transformation, especially changes that will be experienced by students. Also, it will be useful for lecturers who are teaching educational subjects. It is hoped that there will be an imitation process for other lecturers and even the entire academic community in IAI Muhammadiyah Bima.

Besides, the educational science book as one of the reference books at the Tarbiyah Faculty of the Muhammadiyah Islamic Institute has the opportunity to become a reference in influencing the students' mindset, emerging to new intellectual discourses and helping to format the scientific realm at the same time. So the prophetic educational science as a new paradigm in education by making Islam as its foundation will be the answer to the new paradigm format. Therefore, the steps that the researcher will take are integrating the values of prophetic social science into every material contained in the educational science reference book, of course, in one scientific field, that is the prophetic paradigm.

\section{Reconstruction of Educational Sciences through Humanization Values}

Humanization which is derived from the word ta'muruna bil ma'ruf means to «civilized of human being» by eliminating materiality, dependence, violence and hatred from humans, because humanity means "human being", 44 "the condition of being human». In the world of education, humanization must restore human identity as a creature that should be able to apply its human nature (humanity) which has unwittingly begun to disappear. Currently, society is experiencing a process of dehumanization because industrial society has made it part of an abstract society without humanity. ${ }^{45}$ The meaning of «civilized of a human being» is in line with educational goals.

${ }^{43}$ Heddy Shri Ahimsa Putra, Paradigma Profetik Islam Epistemologi, Etos dan Model (Yogyakarta: Gadjah Mada University Press, 2016), 191.

${ }^{44}$ Kuntowijoyo, Muslim Tanpa Masjid, 363.

${ }^{45}$ Kuntowijoyo, Islam Sebagai Ilmu: Epistemologi, Metodologi, dan Etika, 92. 
Humanization in education is crucial for a social goal to spread knowledge. There are several ways to carry out the duties of amr ma'rulf nahi munkar ${ }^{46}$, but education is the only aspect being mandated to make it happen because the purpose of education is to shape the students' personalities. It is a permanent duty for the Muslim community, which must be carried out at all times. ${ }^{47}$ So education stakeholders are also responsible for the lack of humanization value in students because education is not only intended to open someone's minds but also to open their feelings. It means that education is not only used to create a smart figure, but also to create civilized humans. The point is to generate creative humans who are aware of their identity. ${ }^{48}$

According to Paulo Freire, there are two models of education; humanist and de-humanist education. Humanist education provides a broad freedom to think critically. On the other hand, de-humanist education abandons critical thinking, in which teachers position themselves as "gods» as sacred as schools who are untouched by either science or physicality. ${ }^{49}$ The main difference between the two is that dehumanization is a process of transferring knowledge, whereas humanization is a process of empowering people through science. The two are mutually opposing, which then automatically creates a different procedure, which ranges between human consciousness and the world. Dehumanization education is a form of domination and considering human consciousness as merely an empty container that must be filled. Education, meanwhile, as a process of liberation (humanization) views awareness as a «desire» (intention) towards the world. ${ }^{50}$

Humanization is human nature. It is in this humanization process that the ontological vocation of man is to become a subject. At the same time, humans are humans as subjects. Conversely, humans who only adapt will take the position of humans as objects. Meanwhile, adaptation is the most fragile aspect form of self-defence. A person who only adapts will not be able to change the world.

${ }^{46}$ According to Mararif, the doctrine of "amru bil ma'ruf wa nahyu 'anil munkar" can be found in surah al-Arraf: 157, surah Luqman: 17, surah Ali Imran: 104, 110, and 114; and Surah al-Taubah :41. A. Syafi'i Ma'arif, Islam Kekuatan Doktrin dan Kegamangan Umat (Yogyakarta: Pustaka Pelajar, 1997), 8.

${ }^{47}$ Zafar Alam, Islamic Education Theory and Practice (New Delhi: Adam Publisher, 2003), 46-47.

${ }^{48}$ Erlan, 'Mereka Yang Menyongsong Esok Tanpa Nyanyi Dan Puisi', Gerbang Majalah Pendidikan, Oktober 2002, 4 edition, 52.

49 Paulo Freire, Politik Pendidikan: Kebudayaan, Kekuasaan dan Pembebasan (Yogyakarta: Pustaka Pelajar, 2002), 195-96.

${ }^{50}$ Freire, 191. 
Adaptation is a symptom of dehumanization. That is why, in the context of humanization, humans must be able to become subjects. ${ }^{51}$

Also, the problem that deserves attention is that some of the material on education in Indonesia is still an adaptation of educational textbooks based on Western society. This situation has led to a tendency for a pedagogical approach and a psychological approach in the development of education in the country. The pedagogical approach has created people who have alienated themselves and their society because they ignore the fundamental problems of students and do not involve community participation in the educational process. Meanwhile, the psychological approach has alienated society from the development of its society, because psychology used to come from the West, which is sometimes incompatible with the development of Indonesian people. ${ }^{52}$

In the Indonesian context, the two approaches, as mentioned earlier, according to Tilaar, need to be changed to adapt to Indonesian culture, because education is a part of people's lives. So the approach needed is a cultural studies approach, which sees Indonesian people as an inseparable part of Indonesian society and culture itself. ${ }^{53}$ Tharaba emphasizes that education is cultural inheritance. So it is the job of education to pass on cultural values (Islam), because culture will fade or even die if it is not passed on to the next generation, considering that one of the jobs of education is cultural transformation (tarbiyah al-tabligh)..$^{54}$

Epistemologically, the two approaches above are the embodiment of a myopic (narrowing) viewpoint which understate scientific interconnections. It is also seen as a narcissistic viewpoint that exclusively disregards to the benefits of interdisciplinary analysis and context-free perspective. Thus it loses its Indonesian context. This condition has led to some comments that science in Indonesia is an adaptation to science from the Western countries, which is not necessarily fully compatible with the Indonesian culture so that it is emerging, for example, the concept of identifying social science, which did not get an adequate response from Indonesian scientists. ${ }^{55}$

The indigenization of social sciences is one of the efforts of Indonesian scientists who think they need to indigenize science concerning the adoption of sciences to Western culture. Indigenization is Indonesia's national response

${ }^{51}$ Budhy Munawar Rachman, Islam Pluralis: Wacana Kesetaraan Kaum Beriman (Jakarta: Paramadina, 2001), 373.

${ }^{52}$ HAR Tilaar, Kekuasaan Dan Pendidikan (Magelang: Indonesia Tera, 2004), 257-58.

${ }^{53}$ Tilaar, 259.

${ }^{54}$ M. Fahim Tharaba, 'Metodologi Pengembangan Ilmu Pendidikan Islam Perspektif AlQur'an Surat al-Fushilat Ayat 53', Cendekia: Jurnal Kependidikan Dan Kemasyarakatan Vol. 17 No 1 (June 2019): 37-57.

${ }^{55}$ Mahmud Arif, Involusi Pendidikan Islam (Yogyakarta: Idea Press, 6AD), 39. 
to developing the model and forming social science theory, which of course requires quite basic limitations and reasons, considering that cultural differences will lead to differences in objectives and scientific history itself. ${ }^{56}$ The process of indigenization is proof of the scientists' efforts to rebound the knowledge of education in Indonesia to the motherland. This development is in the form of safeguarding the condition and culture of the nation, which cannot be simply eliminated and replaced.

In this context, prophetic education is one concrete example of scientific indigenization process, which makes Islamic values the basis of its foundation, because the majority of Indonesian people are Muslims. Likewise, the condition of the Bima society, they highly uphold Islamic values and even base their philosophy of life on Islamic law. Therefore, the ap plic a tion of the three prophetic values is expected to generate prophetic students.

\section{Reconstruction of Educational Science through Liberation Value}

Liberation is derived from tanhauna anil munkar, which means everything in its connotation with the prevention of evil. Liberation in Latin, liberare, means «to free», so liberation means "liberation». ${ }^{57}$ Liberation in question is liberation in the context of knowledge and based on intangible values, the goal of which also includes a shackling system of knowledge. The liberation of the knowledge system can be interpreted as liberation in the world of education, for example, from class domination and sex.

Thus, liberation in education can be interpreted as an effort to provide equal space and opportunities for men and women in obtaining the opportunity to receive the high est possible education without any restrictions, except for intellectual abilities and things that are against their respective natures. Also, in the public sphere, equality must be given; for example, in the job market, so that one's professionalism and performance only limit it.

Liberation ${ }^{58}$ in education also includes the elimination of class domination. It means that all Indonesian citizens have the same right to education for both the rich and the poor. This assumption indicates that schools and tertiary institutions should provide opportunities for underprivileged citizens to be equally educated

${ }^{56}$ Indigenization is more of a social philosophy review for social science research by looking for a basis for thinking that can support the environment and is contextual in nature, especially in Indonesia. Ignas Kleden, Sikap Ilmiah Dan Kritik Kebudayaan (Jakarta: LP3ES, n.d.), 1-22.

${ }^{57}$ Kuntowijoyo, Muslim Tanpa Masjid, 365.

${ }^{58}$ According to the Engineer, the entire content of the Qoran is based on the spirit of human liberation from exploitation and oppression. So to generate a liberator, the value of freedom must be reflected in the educational process from an early age. Ashgar Ali Engineer, Islam dan Pembebasan (Yogyakarta: LKiS, 1993), 97; Syed M. Naquib Al-Attas, Aims and Objectives of Islamic Education (Jeddah: King Abdul Aziz University, 1979), 126-28. 
together with the rich. It can be through the provision of scholarships or the arrangement of cheap, even free schools. It is, of course, should be given to those who excel or do have special advantages.

In the context of education, liberation can also be interpreted as an effort to increase human dignity, eliminate crime and end oppression and exploitation. Increasing human dignity is the goal of education. It is through education that students are provided with knowledge about various good and bad things, which can differentiate a person's dignity and be able to elevate one's dignity at the same time.

On the other hand, oppression in education can be in the form of an educator's domination of his or her students. This aspect should be abandoned because it can kill the students' power and creativity. Even in a more remote realm, oppression can create a culture of silence. Oppression is a learning culture that is dominated by educators and done by denying students' abilities who sometimes have unexpected potential. This culture of silence will result in killing the students' abilities which are contrary to liberating education.

Liberating education offers "the archaeology of consciousness". One can activate a natural process on its own. It is where consciousness arises from one's ability to perceive himself. In this process reflection grows by itself; one can see the individual instant leap from instinct to understanding. Reflective consciousness causes humans to become capable creatures in understanding things and at the same time understanding themselves. Then consciousness arises as desire, not as an empty container to be filled..$^{59}$

Meanwhile, the banking concept of education only presents facts to students as rote memorization, not building consciousness (critical awareness) of reality through problem-posing education. ${ }^{60}$ Concentration is a process of critical human's participation in change and the process of knowing the world not as a world that is taken for granted, but as a world that is dynamically in the process of formation. Concentration does not ignore changes that produce concrete disclosures and realizations. It is necessary to organize themselves in a revolutionary manner to change the world revolutionarily. ${ }^{61}$

Liberation in education can be in the form of giving students the right to develop their opinions and potentials through dialogue, presenting transformative material and trying to foster students' critical thinking. According to Karolina, every educator realizes the importance of critical thinking skills as a result of the

${ }^{59}$ Freire, Politik Pendidikan: Kebudayaan, Kekuasaan dan Pembebasan, 193.

${ }^{60}$ As a result, until now, Muslims have been left behind in carrying out research activities in the field of empirical inquiry which can produce various theories for research and development of Islamic education. Arif, Pendidikan Islam Transformatif, 217.

${ }^{61}$ Freire, Politik Pendidikan: Kebudayaan, Kekuasaan dan Pembebasan, 183-84. 
learning process. Activeness and critical thinking are integral parts of students' cognitive development as an effort to teach them to be active learners and critical thinkers. ${ }^{62}$ Because, basically learning is a process of positive-qualitative change that occurs in student behavior due to increased knowledge, skills, values, attitudes, interests, appreciation, logical and critical thinking as well as the interactive abilities and creativity that is achieved. ${ }^{63}$

Critical nature is also one of the prerequisites for students to be creative. Because in the critical education paradigm, critical, creative and active aspects of the learning process must be developed. Even liberation and criticism are not two things that can be separated but constituted to become a unity in educational goals. ${ }^{64} \mathrm{~A}$ critical character needs to be addressed at all steps in the learning process, being critical in reading, understanding, asking, answering, discussing and concluding. The critical nature that starts from the learning process is expected to develop and spread to all aspects of life. This trait is increasingly important if students are faced with a problem that will always arise and cannot be avoided in life but must be faced and resolved. ${ }^{65}$

Liberation also means eliminating the title of becoming subject for teachers and objects for students in the educational process. Both are partners whose functions can be exchanged and moved according to conditions and needs. Wekke also emphasized that the teacher is not the main source in the learning process, but as a companion. So that the expected learning outcomes are the growth of learning motivation that encourages creativity. ${ }^{66}$ Through this pattern, it will also create an atmosphere in the educational process that is no longer tense and more enjoyable so that students will more easily understand the material and be able to find their identity.

All educational activities must be able to touch the hearts of students because the heart occupies the centrality of humans as creatures. Also, a person's behavior will be influenced by his heart, and it is through his heart that a person can

${ }^{62}$ Asri Karolina, 'The Implementation of Brain Based Learning to Improve Students' Critical Thinking Ability in Islamic Education Philosophy Course in PAI Study Program STAIN Curup', Cendekia: Jurnal Kependidikan Dan Kemasyarakatan 16, no. 1 (30 July 2018): 190-91.

${ }^{63}$ Abd. Azis, 'Humanisme Dalam Pendidikan Islam: Konsepsi Pendidikan Ramah Anak', Jurnal Pendidikan Agama Islam (Journal of Islamic Education Studies) Volume 5 Nomor1 (2017): 95-115.

${ }^{64}$ Muhammad Qorib and Umiarso El-Rumi, ‘Co(E)Llaborative Of Critical Pedagogy And Islamic Education: Reflections On The Construction Of Religious Humanism Education' Vol. 18, No 1 (2020): 67-84.

${ }^{65}$ Sutrisno, Pendidikan Islam Yang Menghidupkan; Studi Kritis Terhadap Pemikiran Fazlur Rahman (Yogyakarta: Kota Kembang, 2006), 61.

${ }^{66}$ Ismail Suardi Wekke, 'Pesantren dan Pengembangan Kurikulum Kewirausahaan: Kajian Pesantren Roudahtul Khuffadz Sorong Papua Barat', INFERENSI Jurnal Penelitian Sosial Keagamaan 6, no. 2 (Desember 2012): 219. 
accept or reject something, ${ }^{67}$ including education. Thus it is necessary to have a heart in the educational process. A heart that is touched in the educational process will be very easy to convey material (educators), and with a soft heart will very easily accept the material presented (students). ${ }^{68}$

\section{Reconstruction of Educational Sciences through Transcendence Values}

Transcendence is the equivalent of the word tu'minuna billah which in Latin transcendere means "to rise to the top"; in English to transcend is «to penetrate», "to pass through», "to transcend», that means "to travel above or beyond». ${ }^{69}$ Transcendence is in charge of providing a direction to and for humanization and liberation purposes are carried out, because transcendence is the basis. These three elements are an inseparable unity. In the context of transcendence, Kuntowijoyo offers a substitute for methodological secularism and methodological atheism, with methodological objectivism. ${ }^{70}$ Through the method of objectivism, it is hoped that transcendence can become an agent of change and improvement for society, which is objective and impartial to a particular group and is open to non-Muslims. Therefore this good deed is not only done by seeing the object but is done automatically, reflexively and without planning.

The value of transcendence is also a driving force in the realm of education because education without transcendence will overlook God and glorify reason without limits instead. As a result, it will fall into the realm of mere rationality that only recognizes everything that can be sensed (observable) and negates all things that are abstract and invisible, even though they can be felt. Remembering that humans are not only equipped with five visible senses but also conscience and a mind capable of penetrating the invisible.

Therefore, the purpose of education should not only indicate observable matters, even though this should not be taken lightly because it becomes a measure of progress in educational institutions. However, unobservable goals also need to become a special consideration for educational institutions. Remembering human life is not just a realm that can be sensed at this time, but also includes an abstract realm later.

The transcendent meaning of "rising to the top" in education can be understood as instilling the spirit to progress, be the best and achieve a great result. Transcendence leads students to be independent, autonomous, ethical,

${ }^{67}$ Budiman Budiman, 'Eksistensi Spiritualitas Guru Pendidikan Islam Dalam Pembinaan Kompetensi Kepribadian', Cendekia: Journal of Education and Society 14, no. 2 (27 December 2016): 257.

${ }^{68}$ Ivan Riyadi, 'Manajemen Pendidikan Bermuatan Antropologi, Agama Dan Sosial', Cendekia Vol. 17 No 2 (July 2019): 307-308.

${ }^{69}$ Kuntowijoyo, Muslim Tanpa Masjid, 365.

${ }^{70}$ Kuntowijoyo, 373. 
critical, and have high integrity. Thus it will become a "new branding" for the Tarbiyah Faculty in the provision of education. ${ }^{71}$ Achievements should not be neglected, but it should be seen as a challenge to get a higher achievement than previous ones so that it will generate humans who continue to advance and excel. Of course, it must be accompanied by a spirit of faith and divinity, so that it will not violate both divine and social norms.

Godly humans believe that all their actions will be accountable to God. In Islam, a man is responsible for his actions on the day of reckoning. The unified Islamic perspective refuses to distinguish between the sacred and the profane, for example, between prayer and work. ${ }^{72}$ It means that Islam does not only emphasize the aspect of faith but what is more important is how faith is contextualized in deeds because it will have more benefits for the benefit of humankind.

\section{CONCLUSION}

Educational Science reference books at Tarbiyah Faculty of IAI Muhammadiyah Bima use books which do not explicitly contain prophetic elements. The construction of educational science reference books through prophetic social science values is an effort to produce reference books that adopt the values of humanization, liberation and transcendence. The internalization of the three should comply with all material for prophetic education and methods used in learning.

Educational Science should be civilized of a human being; the material provided should contain prophetic elements, empowerment to create a humanist personality. The liberation element can build students' critical and creative power, which can dismiss their way of thinking from the tradition and culture, class domination and sex and eliminate any oppressions. Liberation can also foster the students' consciousness as opposed to a culture of silence to increase their human dignity. The value of transcendence is more like the formation of conscience as a creature that is responsible for God, himself, society and nature. It means that the epistemology of knowledge is not only anthropocentric but theo-anropocentric and even theo-eco-anthropocentric. The choice of material must be observable and unobservable so that one can understand the profane and sacred Islam, which is implemented from iman (faith) accompanied by amal (action). Transcendence also shapes students to be tough, unyielding, not easy to give up, not easily satisfied with their achievements, so that their achievements will continue to increase.

${ }^{71}$ Muhammad Amin Abdullah, Fresh Ijtihad: Manhaj Pemikiran Keislaman Muhammadiyah di Era Disrupsi (Yogyakarta: Suara Muhammadiyah, 2019), 178.

${ }^{72}$ Kuntowijoyo, Muslim Tanpa Masjid, 28-29. 


\section{REFERENCES}

Abdullah, Muhammad Amin. 'Etika Tauhidik sebagai Dasar Kesatuan Epistemologi Keilmuan Umum dan Agama'. In Strategi Pendidikan: Upaya Memahami Wahyu Dan Ilmu. Yogyakarta: Pustaka Pelajar, 2010.

—. Fresh Ijtihad: Manhaj Pemikiran Keislaman Muhammadiyah di Era Disrupsi. Yogyakarta: Suara Muhammadiyah, 2019.

—. 'Islamic Studies in Higher Education in Indonesia: Challenges, Impact and Prospects for the World Community'. Al-Jami'ah: Journal of Islamic Studies 55, no. 2 (15 December 2017): 391-426.

Abdurrahman, Moeslim. Islam Transformatif. Bandung: Pustaka Firdaus, 1999.

Ahmadi, Abu. Ilmu Pendidikan. Jakarta: Rineka Cipta, 2003.

Alam, Zafar. Islamic Education Theory and Practice. New Delhi: Adam Publisher, 2003.

Anwar, M. Syafi'i. Pemikiran dan Aksi Islam Indonesia: Sebuah Kajian Politik tentang Cendekiawan Muslim Orde Baru. Jakarta: Paramadina, 1995.

Arif, Mahmud. Involusi Pendidikan Islam. Yogyakarta: Idea Press, 6AD.

—. Pendidikan Islam Transformatif. Yogyakarta: LKiS, 2008.

__. 'Tipologi Buku Referensi Kependidikan Islam di Fakultas Tarbiyah UIN Sunan Kalijaga Studi Pustaka atas Akar Involusi Konsep Kependidikan Islam’. Penelitian. Yogyakarta: UIN Sunan Kalijaga, 2007.

Arifin, Syamsul. 'Dimensi Profetisme Pengembangan Ilmu Sosial dalam Islam Perspektif Kuntowijoyo'. Teosofi: Jurnal Tasawuf dan Pemikiran Islam 4, no. 2 (Desember 2014).

Azis, Abd. 'Humanisme Dalam Pendidikan Islam: Konsepsi Pendidikan Ramah Anak'. Jurnal Pendidikan Agama Islam (Journal of Islamic Education Studies) Volume 5 Nomor1 (2017): 95-115.

Bakker, Anton. Metodologi Penelitian Filsafat. Yogyakarta: Kanisius, 1990.

Buchori, Mochtar. Ilmu Pendidikan dan Praktek Pendidikan dalam Renungan. Yogyakarta: Tiara Wacana, 1994. 
Budiman, Budiman. 'Eksistensi Spiritualitas Guru Pendidikan Islam Dalam Pembinaan Kompetensi Kepribadian'. Cendekia: Journal of Education and Society 14, no. 2 (27 December 2016): 247.

Engineer, Ashgar Ali. Islam dan Pembebasan. Yogyakarta: LKiS, 1993.

Erlan. 'Mereka Yang Menyongsong Esok Tanpa Nyanyi Dan Puisi'. Gerbang Majalah Pendidikan, Oktober 2002, 4 edition.

Freire, Paulo. Politik Pendidikan: Kebudayaan, Kekuasaan dan Pembebasan. Yogyakarta: Pustaka Pelajar, 2002.

Friedrichs, Robert W. A Sociology of Sociology. London: Free Pers, 1972.

Garaudy, Roger. Janji-Janji Islam. Jakarta: Bulan Bintang, 1984.

Hidayat, Komaruddin. 'Pengantar'. In Sembilan Jalan Cerdas Emosi dan Cerdas Spiritual, xxi. Jakarta: Hikmah, 2006.

Idi, Abdullah. Pengembangan Kurikulum Teori dan Praktik. Yogyakarta: ArRuzz Media, 2010.

Indrawari, Karliana, and Sayyid Habiburrohman. 'Pengembangan Bahan Ajar Pendidikan Agama Islam Dengan Metode Al-Qur 'An Tematik'. Cendekia Vol. 17 No 1 (June 2019): 17-35.

Johnson, Doyle Paulo. Teori Sosiologi Klasik dan Modern. Jakarta: Gramedia Pustaka Utama, 1994.

Jurdi, Syarifuddin. 'Sosiologi Profetik: Invitasi Islam Bagi Studi Sosial Dan Kemanusiaan'. Yogyakarta: Saroba, 2009.

Karolina, Asri. 'The Implementation of Brain Based Learning to Improve Students' Critical Thinking Ability in Islamic Education Philosophy Course in PAI Study Program STAIN Curup'. Cendekia: Jurnal Kependidikan Dan Kemasyarakatan 16, no. 1 (30 July 2018): 189.

Khun, Thomas S. The Structure of Scientific Revolutions -Peran Paradigma dalam Revolusi Sains. Bandung: Remaja Rosdakrya, 2000.

Kleden, Ignas. Sikap Ilmiah Dan Kritik Kebudayaan. Jakarta: LP3ES, n.d.

Kuntowijoyo. Dinamika Sejarah Umat Islam. Yogyakarta: SP dan Pustaka Pelajar, 1994.

—. Identitas Politik Umat Islam. Bandung: Mizan, 1997. 
- Islam Sebagai Ilmu: Epistemologi, Metodologi, dan Etika. Bandung: Mizan, 2005.

—. Muslim Tanpa Masjid. Bandung: Mizan, 2001.

—. Paradigma Islam: Interpretasi Untuk Aksi. Bandung: Mizan, 1991.

_. Paradigma Islam: Interpretasi Untuk Aksi. Yogyakarta: Tiara Wacana, 2013.

M. Amin Abdullah. 'Etika Tauhidik Sebagai Dasar Kesatuan Epistemologi Keilmuan Umum dan Agama (Dari Paradigma Positivistik-Sekularistik ke Arah Teoantroposentrik-Integralistik'. In Integrasi Sains-Islam: Mempertemukan Epistemologi Islam dan Sains, 7-8. Yogyakarta: Pilar Media, 2004.

Ma'arif, A. Syafi'i. Islam Kekuatan Doktrin dan Kegamangan Umat. Yogyakarta: Pustaka Pelajar, 1997.

Moleong, Lexy J. Metodologi Penelitian Kualitatif. Bandung: Remaja Rosdakrya, 2007.

Munip, Abdul. 'Pengembangan Ilmu Pendidikan Islam: Pemetaan Wilayah Kajian'. JIPI 6, no. 1 (2005): 44-45.

Muttaqin, Husnul. 'Menuju Sosiologi Profetik'. Sosiologi Reflektif Volume 10, N0. 1 (Oktober 2015): 219-39.

Northcott, Michael S. 'Pendekatan Sosiologis'. In Aneka Pendekatan Studi Agama, 267. Yogyakarta: LKiS, 2002.

Purnomo, Hadi, and Umiarso. 'Pengelolaan Dan Sistem Pendidikan Islam Berwawasan Rahmatan Lil 'Alamin: Kajian Atas Gerakan Pendidikan Fethullah Gulen Movement'. Cendekia: Jurnal Kependidikan Dan Kemasyarakatan Vol 16, No 2 (2018).

Putra, Heddy Shri Ahimsa. Paradigma Profetik Islam Epistemologi, Etos dan Model. Yogyakarta: Gadjah Mada University Press, 2016.

Qodir, Zuly. 'Kuntowijoyo Dan Kebudayaan Profetik'. PROFETIKA, Jurnal Studi Islam Vol. 16, No. 1 (June 2015): 103-13.

Qorib, Muhammad, and Umiarso El-Rumi. 'Co(E)Llaborative Of Critical Pedagogy And Islamic Education: Reflections On The Construction Of Religious Humanism Education' Vol. 18, No 1 (2020): 67-84. 
Rachman, Budhy Munawar. Islam Pluralis: Wacana Kesetaraan Kaum Beriman. Jakarta: Paramadina, 2001.

Rahardjo, M. Dawam. 'Ilmu Sejarah Profetik Dan Analisis Transformasi Masyarakat'. In Paradigma Islam, 17. Bandung: Mizan, n.d.

Riyadi, Ivan. 'Manajemen Pendidikan Bermuatan Antropologi, Agama Dan Sosial'. Cendekia Vol. 17 No 2 (July 2019): 301-16.

Robertson, Ronald. Agama dalam Analisa dan Interpretasi Sosiologis. Jakarta: Raja Grafindo, 1992.

Rohman, Arif. Memahami Pendidikan dan Ilmu Pendidikan. Yogyakarta: Mediatama, 2009.

Sardar, Ziauddin. Thomas Khun dan Perang Ilmu. Yogyakarta: Jendela, 2002.

Shofan, Moh. Pendidikan Berparadigma Profetik: Upaya Konstruktif Membongkar Dikotomi Sistem Pendidikan Islam. Yogyakarta: Ircisod, 2004.

Sutrisno. Pendidikan Islam Yang Menghidupkan; Studi Kritis Terhadap Pemikiran Fazlur Rahman. Yogyakarta: Kota Kembang, 2006.

Syed M. Naquib Al-Attas. Aims and Objectives of Islamic Education. Jeddah: King Abdul Aziz University, 1979.

Tharaba, M. Fahim. 'Metodologi Pengembangan Ilmu Pendidikan Islam Perspektif Al-Qur'an Surat al-Fushilat Ayat 53'. Cendekia: Jurnal Kependidikan Dan Kemasyarakatan Vol. 17 No 1 (June 2019): 37-57.

Tilaar, HAR. Kekuasaan Dan Pendidikan. Magelang: Indonesia Tera, 2004.

- Perubahan Sosial dan Pendidikan: Pengantar Pedagogik Transformatif untuk Indonesia. Jakarta: Rineka Cipta, 2014.

Wekke, Ismail Suardi. 'Pesantren dan Pengembangan Kurikulum Kewirausahaan: Kajian Pesantren Roudahtul Khuffadz Sorong Papua Barat'. INFERENSI Jurnal Penelitian Sosial Keagamaan 6, no. 2 (Desember 2012): 219.

Zuchdi, Darmiyati. Panduan Penelitian Analisis Konten. Yogyakarta: Lemlit UNY, 1993. 